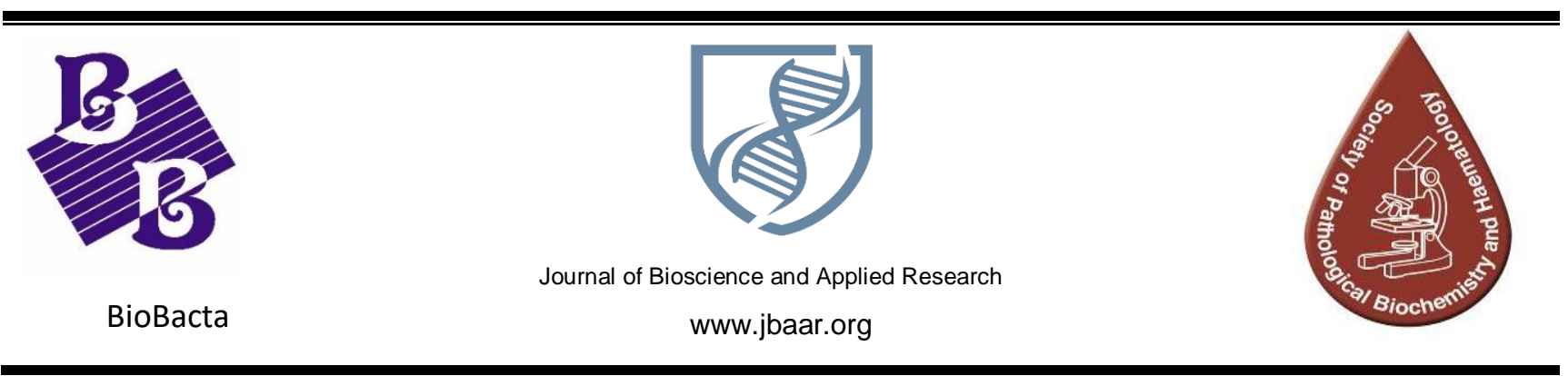

\title{
Evaluation of the in vitro antiplasmodial activity of Millettia zechiana and its action on the evolution of anemia in albino rats.
}

\author{
Karamoko Chérif Moustapha ${ }^{1,2 *}$, Touré André Offianan², Bla Kouakou Brice ${ }^{1}$, Tuo Karim², \\ N'guessan Yao Honoré ${ }^{1}$, Bidie Alain dit Philippe ${ }^{1}$ \\ ${ }^{1}$ University of Félix Houphouët Boigny, 22 PO Box 582 Abidjan 22, Côte d'Ivoire \\ ${ }^{2}$ Institut Pasteur of Côte d'Ivoire, 01 PO Box 490 Abidjan 01 \\ authors' contacts: \\ cherifkaramoko@gmail.com / (225) 77380309 \\ andre_offianan@yahoo.fr / (225) 05636737 \\ blabrice@yahoo.fr / (225) 07579781 \\ karimtuo@pasteur.ci / (225) 08355392 \\ nyaohonore@gmail.com / (225) 09144337 \\ alphbidie@yahoo.fr / (225) 58766797 \\ *Corresponding author, Tel : (225) 77380309; E-mail : cherifkaramoko@ gmail.com
}

\begin{abstract}
Background: Malaria is a parasitic infection that leads to anemia and death. Unfortunately, the upsurge of chemo-resistance prompted researchers to focus on new antimalarial drugs. Objectives: This work aimed to evaluate the antiplasmodial and antianemic activity of Millettia zechiana. Methods: the In vitro activity was assessed on clinical isolates and the standard strain of Plasmodium falciparum K1, using the SYBR green I test. Moreover, the antianemic activity was evaluated in phenylhydrazine-induced anemic albino rats. Results/discussion: The ethyl acetate and hydroethanolic extract exhibited an antiplasmodial activity with $\mathrm{IC}_{50 \mathrm{~s}}$ of 6.14 and $12.14 \mu \mathrm{g} / \mathrm{mL}$ respectively on the Plasmodium falciparum $\mathrm{K} 1$ strain. As for the in vivo antianemic activity, the ethyl acetate extract was the most active with better hematological reconstitution percentages. The presence of chemical compounds such as alkaloids, terpenoids, and quinonic substances in both extracts, could be responsible for their activities. Conclusion: Millettia zechiana could be a potential source for novel antimalarial drugs and might be used as an improved traditional medicine on account of its availability.
\end{abstract}

Keywords : Millettia zechiana; chemosensitivity; anemia; medicine, antiplasmodial

DOI : 10.21608/JBAAR.2019.105889

Received date : December 2, 2018. Accepted : January 15, 2019

J. Biosci. Appl. Res. 


\section{INTRODUCTION}

Malaria is an infectious and life-threatening disease caused by the protozoan parasite Plasmodium. This disease is associated with fever, anemia, and other diseases (Chen et al., 2016). According to the World Health Organization, the prevalence of children suffering from anemia is higher in malaria-endemic areas. Unfortunately, Africa remains the most affected continent with a prevalence estimation ranging from $31 \%$ to $90 \%$ (WHO, 2008). In falciparum malaria, anemia can develop rapidly due to the profound hemolysis of red blood cells (Sumbele et al., 2016) and severe malaria may cause subsequent hypoxia and congestive heart failure (Memendez et al., 2000). Children under 5 years of age account for $70 \%$ of all cases (WHO, 2017). Today, ACTs (Artemisinin-based combination therapies) are the first-line treatment against malaria because of their efficacy against Plasmodium falciparum (WHO, 2015). However, parasites are developing resistance to each new class of known antimalarial drugs, for instance, the upsurge of artemisinin-resistant parasites reported in Cambodia, Thailand, Myanmar, Laos, and Vietnam is a real threat to tremendous efforts to control and eventually eradicate malaria (Cui et $\boldsymbol{a l . ,}$ 2015). The problem is appalling, and new drugs need to be developed (Nondo et al., 2017). The use of medicinal plants for therapeutic purposes has long been practiced (Ogbonna et al., 2008); the success of quinine and artemisinin derivatives against resistant strains of Plasmodium has prompted researchers to cast a glance on medicinal plants for new antimalarial drugs (Akuodor et al., 2012; Olasehinde et al., 2014). Thus, the main purpose of this research work was to evaluate the antiplasmodial and antianemic potential of different extracts of Millettia zechiana.

\section{MATERIALS AND METHODS}

\subsection{Animals}

Forty-two healthy albino Wistar rats of both sexes, weighing between 120 and $210 \mathrm{~g}$ were selected for the study. Animals were kept in polypropylene cages with stainless steel covers and were acclimated for one (1) week under hygienic and standard environmental conditions $\left(23^{\circ} \mathrm{C}\right.$ and $12 \mathrm{~h}$ light/dark cycle) before experimental use. Animals were allowed unrestricted access to water and food pellets (FACI, Abidjan, Côte d'Ivoire). The study protocol was carried out according to the rules and regulations of the Institutional Animal Ethical Committee (IAEC).

\subsection{Plant material}

Stem barks of Milletia zechiana were freshly collected from Saioua in the Western part of Côte d'Ivoire. The sample was identified and authenticated at the National Center of Floristic, University of Felix Houphouët Boigny. Stem barks were air-dried at room temperature $\left(25^{\circ} \mathrm{C}\right)$ for four weeks and ground using an electrically powered engine (IKAMAG RCT ${ }^{\circledR}$ mill, Staufen, Germany). The powder was stored in a moisture-free airtight container for further use.

\subsection{Preparation of crude extracts}

Five successive extractions using the increasing polarity of solvents (Tuo, 2015) were carried out. The polarity order of solvents was as follows: Hexane, Ethyl acetate, Ethanol, Methanol, and distilled water.

One hundred (100) grams of plant powder was weighed using an electronic weighing balance and macerated in one (1) liter of hexane for 24 hours at room temperature $\left(25^{\circ} \mathrm{C}\right)$ using a magnetic stirrer 
brand (IKAMAG RCT Staufen, Germany). The macerate was filtered twice on hydrophilic cotton and once on $3 \mathrm{~mm}$ WHATMANN paper. The filtrate was evaporated to dryness at $40^{\circ} \mathrm{C}$ using a rotary evaporator (BUCHI 161 Water Bath), and the dry powder representing the hexanic extract was stored.

After this extraction, the residual pomace dried. The powder obtained was macerated in one (1) liter of ethyl acetate and the extraction was performed according to the previous method. Successively, hydroethanolic, methanolic, and then aqueous extraction was carried out according to the same method.

Table I: Phytochemical tests

\subsection{Yield of crude extract}

The yield of the crude extract was calculated according to the following formula (Koffi et al., 2015):

$\mathrm{R}(\%)$ : Extraction efficiency in \%.

We: Weigh extract after solvent evaporation.

Wv: Weigh of fine powder used for extraction.

\subsection{Phytochemical qualitative analysis}

Phytochemicals such as steroids, terpenoids, alkaloids, tannins, polyphenols, flavonoids, quinones, and saponins were identified in extracts according to the following standard methods (Mangambu et al., 2014) and summarized in Table I.

\begin{tabular}{ccc}
\hline Phytochemicals & Tests & indicators \\
\hline Alkaloids & Burchard's test & Red-orange precipitate color \\
\hline Flavonoids & Cyanidine test & $\begin{array}{c}\text { Pink-orange or purplish } \\
\text { coloring }\end{array}$ \\
\hline Quinones & Borntrager's test & Reddish or purplish Colouring \\
\hline Polyphenols & Ferric chloride test & Blue blackish Colouring \\
\hline Terpenoids & Liebermann's test & Bleue to green coloring \\
\hline Saponins & Frothing test & Foaming \\
\hline Catechic tannins & Ferric chloride test & Green coloring \\
\hline Gallic tannins & Ferric chloride test & Bleue-blackish coloring
\end{tabular}

\subsection{In vitro antiplasmodial assay}

The In vitro susceptibility assay of Melettia zechiana was carried out against four (4) clinical isolates (Community Health Centre of AnoukouaKouté, Abidjan, Côte d'Ivoire) and resistant Pf Kl strain of Plasmodium falciparum (ATCC MRA159, MR4, ATCC Manassas, Virginia) synchronized culture at $2 \%$ hematocrit. The
Resistant Pf Kl strain of Plasmodium falciparum was maintained in culture according to the method described by Trager and Jensen, (1976). The parasite was maintained at $1.5 \%$ hematocrit in human red blood cells (blood type 0+) in a medium containing RPMI 1640 (Gibco®, Life Technology, UK), $12.60 \mathrm{~mL}$ HEPES buffer ( $25 \mathrm{mM}), 100 \mathrm{~mL}$ hypoxanthine, $312.5 \mu \mathrm{L}$ gentamycin $(40 \mathrm{mg} / \mathrm{mL})$

J. Biosci. Appl. Res. 
and glucose (20 g/L, Wagtech). The culture was grown at $37{ }^{\circ} \mathrm{C}$ in a flask cell culture and confined in a candle chamber saturated with $\mathrm{CO}_{2}$. Parasite growth was monitored microscopically with a Giemsa-stained thin blood smear. Parasite culture was synchronized using 5\% sorbitol before assays. The standard drug (Chloroquine) with concentrations ranging from 3.125 to $1600 \mathrm{nM}$ and crude extracts of Melletia zechiana (at different concentrations from 1.56 to $100 \mu \mathrm{g} / \mathrm{mL}$ ) were prepared in a complete culture medium inside the 96 well microplates. Then, the synchronized culture and the clinical isolates were tested in both standard drug and crude extracts, and microplates were confined in a candle chamber saturated with $\mathrm{CO}_{2}$ and incubated at $37^{\circ} \mathrm{C}$ for $72 \mathrm{hrs}$. After $72 \mathrm{hrs}$ of incubation, $100 \mu \mathrm{L}$ from each well was transferred to a new 96-well microplate. $100 \mu \mathrm{L}$ of a mix containing $5 \mu \mathrm{L}$ of SYBR Green I and $25 \mathrm{~mL}$ of lysis buffer were added to each well and incubated at $37^{\circ} \mathrm{C}$ in darkness for $1 \mathrm{~h}$ before fluorescence reading using a BIOTEK, FLX 800 plate reader (Excitation/Emission: $\quad 485 \mathrm{~nm} / 530 \mathrm{~nm}$ ). All experiments were carried out in duplicates. The antimalarial activity of the test extract was expressed as $\mathrm{IC}_{50}(50 \%$ inhibitory concentration) was determined from a dose-response curve by non-linear regression analysis using WWARN's IVART (In vitro Analysis and Reporting Tool) software (Le Nagard et al., 2011).

\subsection{Anti-anemic activity}

Anemia was induced through intraperitoneal injection of phenylhydrazine at $40 \mathrm{mg} / \mathrm{kg}$ for two (2) days as described by (Yenon $\boldsymbol{e t}$ al., 2015), after injections, rats were divided into nine groups of six rats each.

Group I-Control rats received $10 \mathrm{~mL} / \mathrm{kg}$ distilled water from day 2 to day 22 .
Group II-(negative control) Phenyl hydrazineinduced anemic rats received $10 \mathrm{~mL} / \mathrm{kg}$ of distilled water from day 2 to day 22 .

Group III-(Positive Control) Phenyl hydrazineinduced anemic rats received $1 \mathrm{~mL} / \mathrm{kg}$ of Vitamin $\mathrm{B}_{12}$ from day $\mathrm{y}_{2}$ to day 22 .

Group IV- Phenyl hydrazine-induced anemic rats received a daily dose $(100 \mathrm{mg} / \mathrm{kg})$ of hexanic extract of Milletia zechiana from day 2 to day 22 .

Group V- Phenyl hydrazine-induced anemic rats received a daily dose $(100 \mathrm{mg} / \mathrm{kg})$ of an acetic extract of Milletia zechiana from day 2 to day 22 .

Group VI- Phenyl hydrazine-induced anemic rats received a daily dose $(200 \mathrm{mg} / \mathrm{kg})$ of hexanic extract of Milletia zechiana from day 2 to day $\mathrm{d}_{22}$.

Group VII- Phenyl hydrazine-induced anemic rats received a daily dose $(200 \mathrm{mg} / \mathrm{kg})$ of an acetic extract of Milletia zechiana from day 2 to day 22 .

On completion of the experiment, a blood sample was collected in an EDTA collection tube for each rat to determine biochemical parameters using an automated blood cell counter (Sysmex XN 1000).

\subsection{Statistical analysis}

All values were analyzed using Graph Pad Prism 4 software and the results were expressed as Means \pm standard deviation (SD). One-way analysis of variance (ANOVA) was performed, Significant differences $(\mathrm{P}<0.05)$ between means were compared using the Dunnet post-hoc test.

\section{RESULTS}

\subsection{Extraction efficacy}

The hydro-ethanolic extract of Milletia zechiana had the highest yield recovery of 12.23 while the methanolic extract had the least percentage yield of $0.65 \%$ (Figure 1). The extraction efficacy depends on both the nature and polarity of the solvents used. 


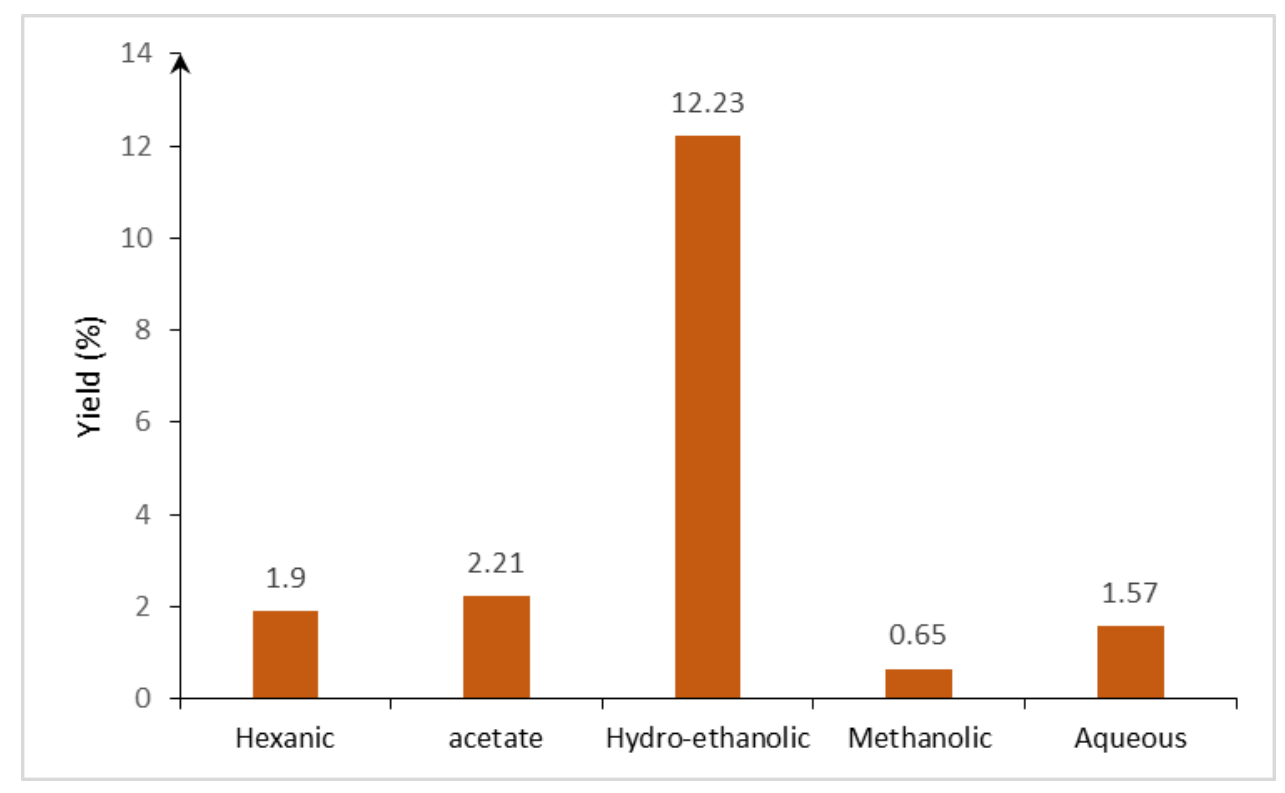

Figure 1: Percentage yield of different extracts of Millettia zechiana

\subsection{Phytochemical Screening}

Alkaloids, steroids, and terpenoids, as well as quinonic substances, are the major chemical compounds found in the different extracts of Millettia zechiana (Table II).

Table II: Phytochemical screening of different extracts of Millettia zechiana

\begin{tabular}{|c|c|c|c|c|c|c|c|c|c|c|}
\hline & & \multirow{4}{*}{$\begin{array}{c}\text { Steroids } \\
\text { and } \\
\text { terper- } \\
\text { noids }\end{array}$} & & & & & & & & \\
\hline & & & \multirow{3}{*}{$\begin{array}{c}\text { Poly- } \\
\text { phenols }\end{array}$} & \multirow{3}{*}{$\begin{array}{c}\text { Flavon } \\
\text { oids }\end{array}$} & \multirow{2}{*}{\multicolumn{2}{|c|}{ Tannins }} & \multirow{3}{*}{$\begin{array}{c}\text { Quinonic } \\
\text { compounds }\end{array}$} & \multirow{2}{*}{\multicolumn{2}{|c|}{ Alkaloids }} & \multirow{3}{*}{ Saponins } \\
\hline & & & & & & & & & & \\
\hline & & & & & Gal & Cat & & D & B & \\
\hline \multirow{5}{*}{$\begin{array}{c}\text { Crude } \\
\text { extract of } \\
\text { Millettia } \\
\text { zechiana }\end{array}$} & Hexane & + & - & - & - & - & - & + & + & - \\
\hline & $\begin{array}{l}\text { Ethyl } \\
\text { acetate }\end{array}$ & + & - & - & - & - & - & + & + & - \\
\hline & $\begin{array}{l}\text { Hydro- } \\
\text { ethanolic }\end{array}$ & + & - & - & - & - & + & + & + & - \\
\hline & $\begin{array}{l}\text { Metha- } \\
\text { nolic }\end{array}$ & + & - & - & - & - & - & + & + & - \\
\hline & Aqueous & + & - & - & - & - & + & + & + & + \\
\hline
\end{tabular}

Presence of compounds: +

Absence of compounds: - 


\subsection{In vitro antiplasmodial test}

The In vitro antiplasmodial study showed that the ethyl acetate and hydroethanolic extract of Milletia zechiana were the most active in the erythrocytic stage of Plasmodium falciparum, with a 50\% inhibitory concentration of parasite growth $\left(\mathrm{IC}_{50 \mathrm{~s}}\right)$ on clinical isolates ranging from 6.07 to 49.45 $\mu \mathrm{g} / \mathrm{mL}$ for the ethyl acetate extract and from 6.04 to $46.32 \mu \mathrm{g} / \mathrm{mL}$ for the hydro-ethanolic extract. Furthermore, tested against the Chloroquineresistant K1 strain, both extracts exhibited a promising antiplasmodial activity with $\mathrm{IC}_{50 \mathrm{~s}}$ of 6.14 (ethyl acetate extract) and $12.14 \mu \mathrm{g} / \mathrm{mL}$ (hydroethanolic extract) (Table III).

Table III: In vitro Antiplasmodial Activity of various extracts of Millettia zechiana against 4 clinical isolates and Chloroquine-resistant $\mathrm{K} 1$ strain $(P f \mathrm{~K} 1)$.

\section{$\mathrm{IC}_{50}$}

\begin{tabular}{lccccc}
$\begin{array}{l}\text { Crude } \\
\text { extracts } \\
(\mu \mathrm{g} / \mathrm{ml})\end{array}$ & Isolate 2 & Isolate 3 & Isolate 4 & Isolate 5 & Pf K1 strain \\
\hline Mhe & $>50$ & $>50$ & $>50$ & $>50$ & $>50$ \\
\hline Mac & 6.07 & 46.69 & 49.45 & 11.79 & 6.14 \\
\hline MHE & 46.32 & 6.09 & 12.35 & 6.04 & 12.14 \\
\hline Mm & $>50$ & $>50$ & $>50$ & $>50$ & $>50$ \\
\hline Maq & $>50$ & $>50$ & $>50$ & $>50$ & $>50$ \\
\hline CQ (nM) & 22.42 & 25.27 & 24.38 & 22.42 & 819.55 \\
\hline
\end{tabular}

\subsection{Antianemic activity}

The intraperitoneal administration of Phenylhydrazine to rats significantly reduced $(\mathrm{P}$ $0.001)$ the red blood cell counts $(52.34 \% 1.135)$, the hemoglobin $(34.61 \%$ 1.717), and the hematocrit $(49.31 \% 0.528)$ levels in rats as compared with normal control on day $2\left(\mathrm{D}_{2}\right)$ (Table IV, V and VI).
After ten (10) days of treatment, these hematological parameters significantly increased (P0.001). Moreover, the ethyl acetate extract of Milletia zechiana was the most active and even appeared to exhibit better activity than the standard drug (Vitamin $\mathrm{B}_{12}$ ). 
Table IV: Effect of Millettia zechiana extracts on red blood cell counts in phenylhydrazine-induced anemic rats.

\begin{tabular}{|c|c|c|c|c|}
\hline \multirow{2}{*}{ Substances } & \multicolumn{4}{|c|}{ Red blood cell counts $\left(10^{6}\right.$ cells/ $\left.\mu \mathrm{l}\right)$} \\
\hline & $\mathbf{D}_{0}$ & $\mathbf{D}_{2}$ & D12 & $\mathbf{D}_{22}$ \\
\hline $\begin{array}{l}\text { Normal control } \\
\text { (Dw } 10 \mathrm{ml} / \mathrm{kg} \text { ) }\end{array}$ & $9,01 \pm 0,26$ & $8,42 \pm 0,30$ & $8,91 \pm 0,41$ & $8,71 \pm 0,30$ \\
\hline $\begin{array}{l}\text { Negative control } \\
(\text { Dw } 10 \mathrm{ml} / \mathrm{kg} \text { ) }\end{array}$ & $9,29 \pm 0,19$ & 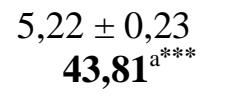 & $\begin{array}{l}5,85 \pm 0,20 \\
\quad+\mathbf{1 2 , 0 7 ^ { b }}\end{array}$ & $\begin{array}{c}6,23 \pm 0,23 \\
+\mathbf{1 9 , 3 4}{ }^{b^{*}}\end{array}$ \\
\hline $\begin{array}{l}\text { Positive control } \\
\text { (Vit } \mathrm{B}_{12} ; 1 \mathrm{~mL} / \mathrm{kg} / \text { day) }\end{array}$ & $8,18 \pm 0,16$ & $\begin{array}{r}4,03 \pm 0,37 \\
\mathbf{5 0 , 7 0} \mathrm{a}^{* * * *}\end{array}$ & $\begin{array}{l}-\quad 6,24 \pm 0,20 \\
\quad+54,72^{b^{* * * *}}\end{array}$ & $\begin{array}{l}7,12 \pm 0,15 \\
+\mathbf{7 6}, \mathbf{4} 7^{\mathrm{b}^{* * * *}}\end{array}$ \\
\hline MHE (100 mg/kg) & $9,56 \pm 0,16$ & $\begin{array}{r}4,99 \pm 0,80 \\
\mathbf{4 7 , 7 8}^{\mathrm{a}^{* * * *}}\end{array}$ & $\begin{array}{r}-\quad 6,88 \pm 0,23 \\
\quad+37, \mathbf{7 9}^{b^{* * * *}}\end{array}$ & $\begin{array}{l}7,41 \pm 0,26 \\
+\mathbf{4 8 , 5 0} \mathbf{b}^{\mathrm{b}^{* * *}}\end{array}$ \\
\hline Mac (100 mg/kg) & $8,10 \pm 0,11$ & $\begin{array}{r}3,54 \pm 0,79 \\
\mathbf{5 6 , 2 4}\end{array}$ & $\begin{array}{r}-\quad 6,29 \pm 0,18 \\
\quad \mathbf{+ 7 7 , 6 2}^{\mathrm{b}^{* *}}\end{array}$ & $\begin{array}{c}6,81 \pm 0,13 \\
\mathbf{+ 9 2 , 2 1}^{\text {b** }}\end{array}$ \\
\hline MHE (200 mg/kg) & $8.13 \pm 0,14$ & $\begin{array}{l}4.13 \pm 0,77 \\
\quad \mathbf{4 9 , 2 0} \mathbf{a}^{\mathrm{a}^{* * * *}}\end{array}$ & $\begin{array}{ll}- & 5.80 \pm 0,89 \\
& +\mathbf{4 0 , 4 1}^{\mathrm{b} * * *}\end{array}$ & $\begin{array}{l}6.49 \pm 0,15 \\
+\mathbf{5 7}, \mathbf{1 4}\end{array}$ \\
\hline Mac (200 mg/kg) & $9.14 \pm 0,42$ & $\begin{array}{r}4.01 \pm 0,11 \\
\quad \mathbf{5 6 , 1 3} \\
\text { a }^{\mathrm{a}^{* * * *}}\end{array}$ & $\begin{array}{r}-7.24 \pm 36 \\
\quad \mathbf{+ 8 0 , 5 5}^{b^{* * * *}}\end{array}$ & $\begin{array}{l}8.81 \pm 0,11 \\
+\mathbf{1 1 9}, \mathbf{7 0} \mathbf{b}^{\mathrm{b}^{* * *}}\end{array}$ \\
\hline
\end{tabular}

Values are expressed as mean $\pm \mathrm{SD}$ (standard deviation) with $\mathrm{n}=6$ in each group. $* * * \mathrm{P}<0.001 ; * * \mathrm{P}<0.01$

a: mean compared to day 0 (D0) in each group; b: compared to day 2 (D2) in each group. Normal control: rats treated with distilled water $(10 \mathrm{ml} / \mathrm{kg})$; negative control: Phenylhydrazine induced anemic rats treated with distilled water (10 $\mathrm{ml} / \mathrm{kg}$ ); Positive control: phenylhydrazine-induced anemic rats treated with Vitamin $\mathrm{B}_{12}$ (1mL/day); MHE: phenylhydrazine induced anemic rats treated with the Hydro-ethanolic extract of Millettia zechiana; Mac: phenylhydrazine induced anemic rats treated with the Ethyl acetate extract of Millettia zechiana, D: Day.

The figures in bold in the table are percentages of the evolution of the evaluated parameter within the different groups of rats. 
Table V: Effect of Millettia zechiana extracts on hemoglobin levels in phenylhydrazine-induced anemic rats.

\begin{tabular}{|c|c|c|c|c|}
\hline \multirow{2}{*}{ Substances } & \multicolumn{4}{|c|}{ Hemoglobin (g/dl) } \\
\hline & $\mathbf{D}_{\mathbf{0}}$ & $\mathbf{D}_{2}$ & D12 & $\mathbf{D}_{22}$ \\
\hline $\begin{array}{l}\text { Normal Control } \\
\text { (Dw } 10 \mathrm{ml} / \mathrm{kg} \text { ) }\end{array}$ & $14,80 \pm 0,61$ & $14,07 \pm 0,41$ & $14,50 \pm 0,72$ & $14,27 \pm 0,55$ \\
\hline $\begin{array}{l}\text { Negative control } \\
\text { (Dw } 10 \mathrm{ml} / \mathrm{kg} \text { ) }\end{array}$ & $15,06 \pm 0,55$ & $\begin{array}{c}10,46 \pm 0,53 \\
\mathbf{- 2 3 , 9 0}\end{array}$ & $\begin{array}{c}12,02 \pm 0,59 \\
\mathbf{+ 2 2 , 3 4}^{\mathrm{b}}\end{array}$ & $\begin{array}{l}12,9 \pm 0,31 \\
+\mathbf{2 8}, \mathbf{4 5}^{\mathrm{b} * *}\end{array}$ \\
\hline $\begin{array}{l}\text { Positive control } \\
\text { (Vit } \mathrm{B}_{12} ; 1 \mathrm{~mL} / \text { day) }\end{array}$ & $14,23 \pm 0,33$ & $\begin{array}{l}8,3 \pm 0,59 \\
\mathbf{- 4 1 , 6 7} \mathbf{a}^{\mathrm{a}^{* * * *}}\end{array}$ & $\begin{array}{l}13,70 \pm 0,52 \\
\mathbf{+ 6 5 , 0 6}^{\mathrm{b}^{* * * *}}\end{array}$ & $\begin{array}{l}14,27 \pm 0,52 \\
+71,92^{\mathrm{b}^{* * *}}\end{array}$ \\
\hline MHE (100 mg/kg) & $15,64 \pm 0,30$ & $\begin{array}{l}10,58 \pm 0,21 \\
\mathbf{- 3 2 , 3 5}^{\mathrm{a}^{* * * *}}\end{array}$ & $\begin{array}{c}14,60 \pm 0,19 \\
+\mathbf{3 8}^{\mathrm{b}^{* * * * *}}\end{array}$ & $\begin{array}{c}14,63 \pm 0,33 \\
+\mathbf{3 8}, \mathbf{2 8}\end{array}$ \\
\hline Mac (100 mg/kg) & $14,24 \pm 0,42$ & $\begin{array}{c}8,125 \pm 1,79 \\
\mathbf{- 4 2 , 9 4}\end{array}$ & $\begin{array}{c}14,83 \pm 0,64 \\
+\mathbf{8 2}, \mathbf{5 2} \\
{ }^{\mathrm{b}^{* * *}}\end{array}$ & $\begin{array}{c}14,23 \pm 0,28 \\
\mathbf{+ 8 3 , 7 5}^{\mathrm{b} * *}\end{array}$ \\
\hline MHE (200mg/kg) & $15.69 \pm 0,13$ & $\begin{array}{l}10.18 \pm 0,22 \\
\mathbf{- 3 5 , 1 2}^{\mathrm{a}^{* * * *}}\end{array}$ & $\begin{array}{l}14.52 \pm 0,69 \\
\mathbf{+ 4 2 , 6 3}^{\mathrm{b}^{* * * *}}\end{array}$ & $\begin{array}{l}14.74 \pm 0,34 \\
+\mathbf{4 4 , 7 9} \mathrm{b}^{\mathrm{b} * * *}\end{array}$ \\
\hline Mac (200mg/kg) & $15.08 \pm 0,34$ & 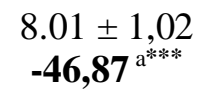 & $\begin{array}{l}14.89 \pm 0,45 \\
\mathbf{+ 8 5 , 8 5}^{\text {b**** }}\end{array}$ & $\begin{array}{l}15.99 \pm 0.52 \\
+\mathbf{9 9 , 5 8}\end{array}$ \\
\hline
\end{tabular}

Values are expressed as mean $\pm \mathrm{SD}$ (standard deviation) with $\mathrm{n}=6$ in each group. $* * * \mathrm{P}<0.001 ; * * \mathrm{P}<0.01$ a: mean compared to day 0 (D0) in each group; b: compared to day 2 (D2) in each group. Normal control: rats treated with distilled water $(10 \mathrm{ml} / \mathrm{kg})$; negative control: Phenylhydrazine induced anemic rats treated with distilled water (10 $\mathrm{ml} / \mathrm{kg}$ ); Positive control: phenylhydrazine-induced anemic rats treated with Vitamin $\mathrm{B}_{12}$ (1mL/day); MHE: phenylhydrazine induced anemic rats treated with the Hydro-ethanolic extract of Millettia zechiana Mac: phenylhydrazine induced anemic rats treated with the Ethyl acetate extract of Millettia zechiana, D: Day.

The figures in bold in the table are percentages of the evolution of the evaluated parameter within the different groups of rats. 
Table VI: Effect of Millettia zechiana extracts on hematocrit levels in phenylhydrazine-induced anemic rats.

\begin{tabular}{|c|c|c|c|c|}
\hline \multirow[b]{2}{*}{ Substances } & \multicolumn{4}{|c|}{ Hematocrit (\%) } \\
\hline & $\mathbf{D}_{0}$ & $\mathbf{D}_{2}$ & D12 & $\mathbf{D}_{22}$ \\
\hline $\begin{array}{l}\text { Normal Control } \\
\text { (Dw } 10 \mathrm{ml} / \mathrm{kg} \text { ) }\end{array}$ & $51,70 \pm 2,08$ & $47,80 \pm 1,65$ & $51,90 \pm 2,10$ & $50,83 \pm 2,07$ \\
\hline $\begin{array}{l}\text { Negative control } \\
\text { (Dw } 10 \mathrm{ml} / \mathrm{kg} \text { ) }\end{array}$ & $52,00 \pm 1,56$ & $\begin{array}{c}27,16 \pm 1,07 \\
\mathbf{- 4 3 , 9 2}\end{array}$ & $\begin{array}{c}33,36 \pm 2,408 \\
+\mathbf{1 4 , 4} \mathbf{4}^{\mathrm{b}}\end{array}$ & $\begin{array}{c}35,06 \pm 1,627 \\
\quad+\mathbf{2 0 , 2 3} \mathbf{2 3}^{\mathrm{b}^{*}}\end{array}$ \\
\hline $\begin{array}{l}\text { Positive control } \\
\text { (Vit } \mathrm{B}_{12} ; 1 \mathrm{~mL} / \text { day) }\end{array}$ & $48,85 \pm 0,99$ & $\begin{array}{l}23,13 \pm 1,62 \\
-\mathbf{4 8 , 5 6}\end{array}$ & $\begin{array}{c}49,47 \pm 1,75 \\
+\mathbf{7 6 , 6 8}\end{array}$ & $\begin{array}{c}49,48 \pm 1,07 \\
+\mathbf{8 5 , 9 7}\end{array}$ \\
\hline MHE $(100 \mathrm{mg} / \mathrm{kg})$ & $54,66 \pm 1,00$ & $\begin{array}{r}25,96 \pm 0,61 \\
\mathbf{4 8 , 8 5} 5^{\mathrm{a}^{* * * *}}\end{array}$ & $\begin{array}{l}-\quad 49,4 \pm 0,59 \\
\quad+76,68 \\
b^{b^{* * *}}\end{array}$ & $\begin{array}{c}52,00 \pm 0,93 \\
\mathbf{+ 8 5 , 9 8}^{b^{* * * *}}\end{array}$ \\
\hline Mac (100mg/kg) & $48,92 \pm 1,20$ & 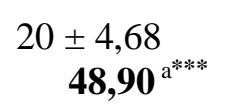 & $\begin{array}{r}-\quad 47,13 \pm 1,70 \\
\quad+\mathbf{8 8 , 5 2}\end{array}$ & $\begin{array}{l}51,6 \pm 1,04 \\
+\mathbf{1 0 6}, \mathbf{4}^{\mathrm{b}^{* * *}}\end{array}$ \\
\hline MHE $(200 \mathrm{mg} / \mathrm{kg})$ & $54.08 \pm 0,78$ & $\begin{array}{r}27,16 \pm 0,14 \\
\mathbf{4 9 , 7 8}\end{array}$ & $\begin{array}{r}-48,89 \pm 0,81 \\
\quad+\mathbf{8 0 , 0 1} \mathbf{b}^{\mathrm{b}^{* * * *}}\end{array}$ & $\begin{array}{r}53,83 \pm 0,39 \\
+\mathbf{9 8 , 1 9}\end{array}$ \\
\hline Mac (200mg/kg) & $50.19 \pm 0,19$ & $\begin{array}{r}24.89 \pm 0,56 \\
\mathbf{5 0 , 4 1} 1^{\mathrm{a}^{* * * *}}\end{array}$ & $\begin{array}{r}\quad 47.89 \pm 0,75 \\
+\mathbf{9 2 , 4 1}\end{array}$ & $\begin{array}{l}54.55 \pm 1,06 \\
\mathbf{+ 1 1 9 , 1 6}^{\text {b**** }}\end{array}$ \\
\hline
\end{tabular}

Values are expressed as mean $\pm \mathrm{SD}$ (standard deviation) with $\mathrm{n}=6$ in each group. ${ }^{*} * * \mathrm{P}<0.001 ; * * \mathrm{P}<0.01$. a: mean compared to day 0 (D0) in each group; b: compared to day 2 (D2) in each group. Normal control: rats treated with distilled water $(10 \mathrm{ml} / \mathrm{kg})$; negative control: Phenylhydrazine-induced anemic rats treated with distilled water $(10$ $\mathrm{ml} / \mathrm{kg}$ ); Positive control: Phenylhydrazine induced anemic rats treated with Vitamin $\mathrm{B}_{12}(1 \mathrm{~mL} / \mathrm{day})$; MHE: phenylhydrazine induced anemic rats treated with the Hydro-ethanolic extract of Millettia zechiana Mac: phenylhydrazine induced anemic rats treated with the Ethyl acetate extract of Millettia zechiana, D: Day.

The figures in bold in the table are percentages of the evolution of the evaluated parameter within the different groups of rats.

\section{DISCUSSION}

This work aimed to evaluate the in vitro antiplasmodial activity of five extracts of Millettia zechiana and extracts showing high potential were selected to assess their anti-anemic activity in phenylhydrazine-induced anemia in rats.

Therefore, extracts were prepared from solvents with increasing polarity. The extraction yield percentage $(12.23 \%)$ of the hydro-ethanolic extract of Millettia zechiana was the highest. This could mean that this extract contains more polar compounds than the others. The phytochemical screening results showed that all extracts contained terpenoids and alkaloids. However, Quinones were only detected in the hydro-ethanolic and aqueous extracts.

The in vitro antiplasmodial tests revealed that only two extracts were active on both clinical isolates 
and the chloroquine-resistant $\mathrm{K} 1$ strain, according to the classification scale of Jansen et al., (2012). According to these authors, the hydro-ethanolic and ethyl acetate extracts of Milletia zechiana have promising and moderate activity against clinical isolates of Plasmodium falciparum and chloroquine-resistant K1 strain. The studies of Zihiri et al., 2005 and 2010 showed that the ethanolic extract of Millettia zechiana had good antiplasmodial activity ( $\mathrm{IC}_{50 \mathrm{~s}}$ of 16.1 and 14.1 $\mu \mathrm{g} / \mathrm{mL}$ ) and these previous results matched with those found with the hydro-ethanolic extract $\left(\mathrm{IC}_{50}=\right.$ $12.14 \mu \mathrm{g} / \mathrm{mL}$ ) in this study.

Ethyl acetate and hydro-ethanolic extracts with outstanding antiplasmodial potentials were selected for the anti-anemic activity assay.

Therefore, anemia was induced by intraperitoneal injection of phenylhydrazine (Phz) at a dose of 40 $\mathrm{mg} / \mathrm{kg}$ for 2 days.

Phenylhydrazine causes hemolytic anemia in rats by decreasing the level of red blood cell counts, hemoglobin, and hematocrit (Yenon et al., 2015). This anemia is characterized by the early lysis of red blood cells, which was reversed 12 days later after administration of the ethyl acetate extract of Millettia zechiana. This result could be due to the presence of alkaloids in this extract since alkaloids and flavonoids are powerful antioxidants that prevent or repair the damage done to red blood cells by free radicals or highly reactive oxygen species (Ogbe and Adoga, 2010). Turaaskar (2013) reported that most anti-anemic compounds are known for their free radical scavenging activity that reverses anemic conditions. This phytochemical might have contributed to the anti-anemic activity of Millettia zechiana observed in the present study by stimulating erythropoiesis in the bone marrow. Thus, the difference between the activities of both extracts could be because they do not have similar phytochemical compounds (Saravanan and Manokaran, 2012).

\section{CONCLUSION}

This study provides evidence that both the ethyl acetate and hydro-ethanolic extracts of Millettia zechiana exhibited a good antiplasmodial potential. Furthermore, it appears that the ethyl acetate extract has a very good anti-anemic activity. The results, therefore, demonstrate that Millettia zechiana is a real asset in the search for new antimalarial and anti-anemic drugs. Nevertheless, further studies need to be undertaken to ascertain the in vivo toxicity of this plant and identify its active principles.

\section{COMPETING INTERESTS}

The authors have declared that no competing interests exist.

6. REFERENCES TO BIBLIOGRAPHIQUES Akuodor, G.C., Amos, G.M., Essien, A.D., Essien, D.O., Akpan, J.L., Ezeokpo, B.C. (2012). Antimalarial potency of the leaf extract of Aspilia Africana (Pers.) C.D Adams. Asian Pacific Journal of Tropical Medicine., 5 (2): 126-129.

Chen, I., Clarke, S.E., Gosling, R., Hamainza, B., Killeen, G., Magill, A., O'Meara, W., Price, R.N., Riley, E.M. (2016). Asymptomatic malaria: a chronic and debilitating infection that should be treated. PLoS Medicine., 13 (1): e1001942.

\section{Cui, L., Mharakurwa, S., Ndiaye, D., Rathod,} P.K., Rosenthal, P.J. (2015). Antimalarial drug resistance literature review and activities and finding of the ICEMR network. The American Journal of Tropical Medicine And Hygiene., 93 (3): $57-68$ 
Jansen, O., Tits, M., Angenot, L., Nicolas, J.P., De Mol, P., Nikiema, J.B., Frédérich, M. (2012). Anti-plasmodial activity of Dicoma tomentosa (Asteraceae) and identification of urospermal A-15$\mathrm{O}$-acetate as the main active compound., Malaria Journal, 11: 1-9.

Koffi, A.J., Bla, K.B., Yapi, H.F., Bidie, A.P., Djaman, A.J. (2015). Phytochemical Screening of Some Medicinal Plants in Côte D'ivoire and Evaluation of their Extraction Efficiency. International Journal of Pharmacognosy and Phytochemical Research., 7 (3): 563-569.

Le Nagard, H., Vincent, C., Mentre, F., Le Bras, J. (2011). Online analysis of in vitro resistance to antimalarial drugs through nonlinear regression. Computer Methods and Programs in Biomedicine., 104: 10-18.

Mangambu, M.J.D., Mushagalusa, K.F., Kadima, N.J. (2014). Contribution à l'étude photochimique de quelques plantes médicinales antidiabétiques de la ville de Bukavu et ses environs (Sud-Kivu, R.D.Congo). Journal of Applied Biosciences., 75: 6211-6220.

Menendez, C., Fleming, A.F., Alonso, P.L., (2000). Malaria-related anemia. Parasitol Today., 16 (11): 469-476.

Nondo, R.S.O., Moshi, M.J., Erasto, P., Masimba, P.J., Machumi, F., Kidukuli, A.W., Heydenreich, M., Zofou, D. (2017). Antiplasmodial activity of norcaesalpin D and extracts of four medicinal plants used traditionally for treatment of malaria. BMC Complementary and Alternative Medicine 17: 167-175.
Ogbe, R.J and Adoga, G.I. (2010). Antianaemic potentials of some plant extracts on phenyl hydrazine-induced anaemia in rabbits. Journal of Medicinal Plants Research., 4: 680-684.

Ogbonna, D.N., Sokari, T.G., Agomuoh, A.A. (2008). Antimalarial activities of some selected traditional herbs from Southeastern Nigeria against Plasmodium Species. Research Journal of Parasitology; 3 (1): 25-31.

Olasehinde, G.I., Ojurongbe, O., Adeyeba, A.O., Fagade, O.E., Valecha, N., Ayanda, I.O., Ajayi, A.A., Egwari, L.O. (2014). In vitro studies on the sensitivity pattern on Plasmodium falciparum to anti-malaria drugs and local herbal extracts. Malaria Journal., 13 (1): 63-69.

Saravanan, V.S and Manokaran, S. (2012). Antianaemic activity of some plants in Cucurbitaceae on phenylhydrazine-induced anaemic rats. Thailand Journal of Pharmaceutical Sciences., 36: 150-154.

Sumbele, I.U.N., Sama, S.O., Kimbi, K.H., and Taiwe, S.G. (2016). Malaria, Moderate to Severe Anaemia, and Malarial Anaemia in Children at Presentation to Hospital in the Mount Cameroon Area: A Cross-Sectional Study. Anemia. http://dx.doi.org/10.1155/2016/5725634., 12p.

Trager, W., Jensen, J.B. (1976). Human malaria parasite in continuous culture. Science., $193: 673$ 675.

Tuo K. (2015). Criblage phytochimique, activité antioxydante et antiplasmodiale in vitro de cinq plantes utilisées traditionnellement en Côte d'Ivoire contre le paludisme. Doctorat d'Université Thèse Unique, Université Félix Houphouët Boigny, 200p. 
Turaskar, A., More, S., Sheikh, R., Gadhpayle, J., Bhongade, S.L. (2013). Inhibitory potential of Picrorrhiza kurroa royle ex. extract on phenyhydrazine induced reticulocytosis in rats. Asian Journal Pharmaceutical and Clinical Research., 6 (2): 215-216.

WHO. (2008). Worldwide prevalence of anemia 1993-2005: WHO global database on anemia / Edited by Bruno de Benoist,

WHO. World malaria report (2015). Geneva, 280p.

WHO. World malaria report (2017). Geneva, 196p.

Yenon, A.A., Yapi, H.F., Gnahoue, G., Yapo, A.F., Nguessan, J.D and Djaman, A.J. (2015). Anti-anaemic activity of aqueous and ethanolic extracts of Entandrophragma angolense bark on phenylhydrazine-induced anaemic rats. Asian Journal of Biochemical and Pharmaceutical Research., 5 (3): 12-21.

Zihiri, N.G., N'Guessan, K., Etien, T.D., Grellier, P. (2010). Ethnopharmacological study of plants used to treat malaria in traditional medecine, by Bete populations of Issia (Côte d'Ivoire). Journal Pharmcology Science and Research., 2: 216-227.

Zirihi, G. N., Mambu, L., Guede-guina, F., Bodo, B. and Grellier, P. (2005). In vitro antiplasmodial activity and cytotoxicity of 33 West African plants used for treatment of malaria. Journal of Ethnopharmacology, 98: 281-285. 